\title{
TRANSPARENCY PRINCIPLES IN INFORMED CONSENT OF SURGICAL PROCEDURES TO REDUCE MEDICAL DISPUTE RISK
}

\author{
Carolina Kuntardjo, dr., SpB., FICS., M.H. \\ Email: drcarolinabedah@yahoo.com \\ Agus Yudha Hernoko, S.H., M.H., Dr. Prof. \\ Email: yudha_fhunair@yahoo.co.id
}

\begin{abstract}
Objective: Informed consent is one element of ethics in medical field that is always interesting to explore. Currently, the development of informed consent is more emphasized on disclosure of information, in other words, in it can be equated with transparency. The thesis entitled TRANSPARENCY PRINCIPLES IN INFORMED CONSENT OF SURGICAL PROCEDURES TO REDUCE MEDICAL DISPUTE RISK" will address the importance of transparency principle in informed consent of surgical actions and the settlement of medical disputes due to the absence of transparency in informed consent. Surgical science has distinct and special characteristics compared to other medical fields, especially in the case of doctor-patient relation, where the transparency of the surgeon and the patient plays an important role to take a decision on surgery. Unfortunately, the existence of ethical gap causes transparent process of providing information cannot be realized properly, especially because of ineffective communication between surgeons and patients. This will be vulnerable to conflict between surgeons and patients who will lead to medical disputes. The purpose of this study was to analyze the importance of transparency in informed consent surgery and how to resolve medical disputes due to the absence of transparency in informed consent.
\end{abstract}

Method: This study uses normative juridical method by studying norms or rules in positive law.

Outcome: Implementing transparency in informed consent is expected to reduce the incidence of medical disputes, therefore, the need for standardization of transparency in informed consent is necessary. If a medical dispute occurs, the non-litigation settlement shall be settled by means of mediation before proceeding to the law so as to create a favorable condition for both parties. Because mediation in medical disputes has a specificity it is necessary to have a separate regulation to regulate it.

Keywords: transparency, informed consent, medical dispute, mediation 


\section{THE IMPORTANCE OF TRANSPARENCY PRINCIPLES IN THE INFORMED CONSENT PROCESS OF SURGICAL PROCEDURES \\ 1.1 Medical Surgical Procedure Characteristics}

Surgical procedure is defined as a medical procedure done by performing an incision using a tool with the aim to overcome the damage or disease in a living body. ${ }^{1}$ Surgery has specific characteristics compared to non-surgical medical procedures in terms of patients, physicians, and illnesses and its situations. Patients who will undergo surgery would certainly face a much different situation psychologically than non-surgical patients. ${ }^{2}$ These situations will certainly affect the process of acceptance and understanding of information, which will also affect the decision-making process of medical procedure offered by doctors. Often a surgeon does not have enough time to explain clearly to the patient or his family, not even allowing them to ask questions. In one study, it was found that very few patients dared to discuss with surgeons during the clinic visit, this situation was exacerbated by the fact that only $38 \%$ of the surgeons responded positively to the patient's desire to have a discussion. ${ }^{3}$ While patients are under conditions of total anesthesia, surgeons surely in superior position to determine and control the situation even to make decisions for patients at the time. ${ }^{4}$

Another issue in a surgical medical procedure related to ethics is the possibility of conflict of interest, especially related to financial problems or, in other words, economic interest. Associated with ethics as the code of professional conduct and professionalism, doctors need to consider the term physician rates. In English, medical services are usually referred to as doctor's charge. In the Indonesian language, it is often called the doctor's rates. ${ }^{5}$ Nevertheless, the term doctor's charge is not appropriate to refer to the rewards of services that have been made by doctors; it is more proper to refer to it as medical services or doctor's honorarium.

\subsection{Informed Consent Surgical Procedure Philosophy}

Based on a survey on surgical literature, it was found that only $0.6 \%$ of the literature discusses the ethics in the field of surgery compared to other medical fields, which discuss ethics as much as $2.7 \%$ of the journals. This is called the ethics gap in the field of surgery, which mainly deals with the character of surgeons and the understanding of ethics that is considered trivial in the education of doctors and surgeons. ${ }^{6}$

Informed consent cannot only be regarded as a consent of medical procedure, but it may be also a rejection of medical procedures even though doctors know best. All of these are related to the right of the patient to decide for himself (the right of self-determination). Informed consent is also not just a moment to get a patient's signature or to fill in the form of consent or rejection towards medical procedure, but is a series of process of patient's understanding on the doctor's information which will have implications for decision-making

\footnotetext{
${ }^{1}$ http://www.mnemonicdictionary.com

${ }^{2}$ Susan Ayers, Andrew Baum, Chris McManus, et al. Cambridge Handbook of Psychology, Health and Medicine, Cambridge University Press, 2007. P.506

${ }^{3}$ James W. Jones, Laurence B. McCullough, Bruce W. Richman., The Ethics of Surgical Practice: cases, dilemmas, and resolutions. Oxford University Press, 2008, p.7

${ }^{4}$ Laurence B. McCullough, James W. Jones, Baruch A. Brody., Surgical Ethics, Oxford University Press, 1998, p. 15

${ }^{5}$ Abdulkadir Muhammad, Op.Cit., h.58

${ }^{6}$ Robert M. Sade, The Ethics of Surgery: Conflicts and Controversies, Oxford University Press, 2015, p.20
} 
for the patient's own self. The process of informed consent need an autonomy from doctors and patients, even it may also depends on some external factors. Informed consent as a pocess, not just an event, has three stages including negotiation, agreement, and permission to get a consent. The process can be described as in diagram bellow : ${ }^{7}$

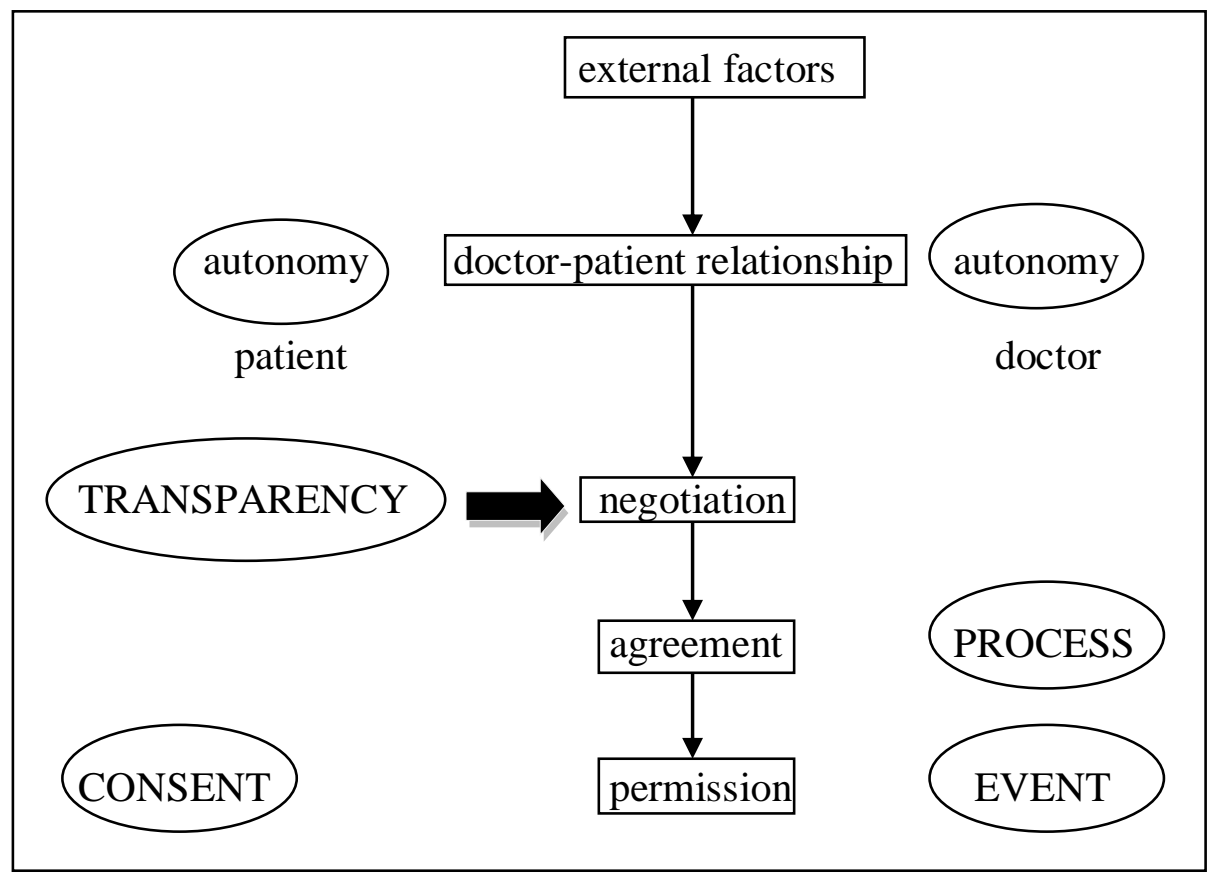

The process of informed consent of surgical patients includes several stages which are referred to as the preoperative pathway, comprising preoperative care, intra-operative care, and postoperative care. Time constraints in an informed consent process are the things that often cause problems, since understanding a surgical process including the possible risks is not an easy matter. Ideally, the process of informed consent is done by the doctor in charge of service (Dokter Penanggung Jawab Pelayanan), the doctor who will perform surgery. It should be noted that if the surgeon delegates the informed consent process to a doctor on duty or nurse, and there is an error in the provision of informed consent, the surgeon remains responsible in accordance with the vicarious liability principle. There should be rules governing who is entitled to replace the process of execution of informed consent, as well as the legal consequences arising from the process of execution of informed consent made by surgeons who will perform surgery.

\subsection{Doctor-Patient Relationship}

The relationship between a doctor and a patient in the international literature is called a doctor-patient relationship or clinician-patient relationship. In Indonesia, the relationship between doctors and patients still use different terms; some address it as therapeutic transaction, therapeutic contracts, or therapeutic agreements.

The doctor-patient relationship does indeed lead to equality, not paternalism. But, the actual doctor-patient relationship is more precisely embodied in a "proportional" relationship,

${ }^{7}$ Alasdair Maclean, Op.Cit.,p.144 
which is, in Kamus Besar Bahasa Indonesia, is defined as proportional, equal, or balanced. ${ }^{8}$ It is undeniable that doctors and patients are not in the same position, but this position should not be utilized by the dominant party to impose its will. The nature of doctor-patient relationship as a form of contract is inseparable from the principle of justice, in the sense that there is a principle of fair exchange of interests like contracts in general.

The doctor-patient relationship is inseparable from the bioethics aspect because it concerns the ethics of the medical profession, in this case the doctor in charge. There are seven principles in medical ethics according to the American Medical Association or commonly referred to as AMA Code: ${ }^{9}$ autonomy, beneficence, maleficence, confidentiality, justice, role fidelity, veracity. In order for the physician-patient relationship to proceed properly, some characteristics are necessary: ${ }^{10}$ trust, respect, morally responsible to the others, empathy, and care.

\subsection{Rights and Responsibilities of Related Parties}

According to the declaration of the rights of patients in Europe in 1994, patients have the following rights: ${ }^{11}$

a. The right to be respected as a human being.

b. The right to self-determination.

c. The right to security (right to physical and mental integrity and self-security).

d. The right to have moral values, culture, religion, and philosophical respect

After the AHA Patient's Bill of Rights, the legal aspects of patient' rights related to informed consent are taught to medical faculty students. A survey conducted in the USA in 1978 indicated that there were 66 educational institutions that included materials on informed consent in the medicolegal area. ${ }^{12}$

If a patient does not perform his duty in providing clear and correct information about his condition and his medical history, it will be difficult for the doctor to provide a treatment plan for the patient

\subsection{The Legality of Informed Consent in accordance to Section 1320}

As any other forms of agreement, informed consent as an agreement must also meet the requirements of the validity of an agreement as set forth in article $1320 \mathrm{BW}:{ }^{13}$

1. Agreement between contractors (art 1321-1328 BW).

2. The parties are competent in performing legal acts (article 1329-1331 BW).

3. The object of agreement can be determined (article 1332-1334 BW).

4. Kausa halal or allowed (article 1335-1337 BW).

In the Permenkes on Approval of Medical Procedures Articles 13 and 16, are outlined about the consent and rejection of medical procedure carried out by the patient and/or his/her immediate family. There is no explanation of anyone who may give or reject a consent of

\footnotetext{
${ }^{8}$ Agus Yudha Hernoko-1, Op.Cit., h.75

${ }^{9}$ Karen Judson, Carlene Harrison, Law \& Ethics for Health Professions, McGraw Hill, New York, 2013, p.38

${ }^{10}$ Alasdair Maclean, Op.Cit,p.77

${ }^{11}$ Declaration on the Promotion of Patients' Rights in Europe, European Consultation of the Rights of Patients, Amsterdam 1994

${ }^{12}$ Ruth R. Faden, Tom L. Beauchamp, Op.Cit., p.95

${ }^{13}$ Moch Isnaeni, Op.Cit, h.12
} 
medical treatment, whether the patient's immediate family based on kinship rules or whether the family that may be there at that time. The issues related this decision making is not merely on the patient's side, but there must be a review on the doctor's side as well. Doctors as the executor of medical procedure must also have competence in accordance with the field.

\subsection{Transparency in Informed Consent of Surgical Procedures}

The term transparency began to be used frequently in the 1960s and 1970s and in the field of law, the term is more often referred to as "disclosure". According to a research conducted by the Responsible Data Science (RDS), a consortium in the Netherlands consisting of a variety of disciplines, transparency in the field of science such as health is intertwined with fairness, confidentiality, and accuracy, or abbreviated as FACT (Fairness, Accuracy, Confidential, Transparency). ${ }^{14}$ In the health field, there are four types of transparency: ${ }^{15}$

1. Transparency between clinicians and patients.

2. Transparency among clinicians.

3. Transparency among organizations.

4. Transparency to the publics.

Dishonesty in the exchange of information is something that will be at risk to lead to different views of doctors and patients. Disclosure of information from the patient includes the description of the illness that is being suffered, the overall state of the body, the state or family health history, and information about the patient's habits including his previous medical history. Meanwhile, the disclosure of doctors in accordance with the Regulation of Minister of Health Number: 290/Menkes/PER/III/2008 about the Approval of Medical Action Article 7 shall at least include:

1. Diagnosis and procedure of medical procedure.

2. The purpose of the medical procedure performed.

3. Alternative procedures and risks.

4. Risks and complications that may occur.

5. Prognosis of the procedure taken.

6. Financing estimation.

Article 9 states that an explanation should be given thoroughly with eligible language to ensure understanding. In this case, it is actually clear that the transparency or openness of information between doctors and patients should be upheld and even written rules have been made. Although it is not clear what sanctions will be given if this principle of transparency is not implemented.

In 2015 the Dutch Health Ministry proclaimed the year of transparency program, as a continuation of health politics in Holland which focuses on patient right and patient choice for years. Transparency is aimed at improving the standard of health services, especially on the availability of access to information on the quality of health services. ${ }^{16}$ The establishment

\footnotetext{
${ }^{14}$ Wil van der Aalst, Responsible Data Science Ensuring Fairness, Accuracy, Confidentiality, and Transparency (FACT), 2016, Available at: http://www.responsibledatascience.org/

15 Shinning Light: safer health care through transparency, Op.cit., P.7

${ }^{16}$ Madelon Kroneman et al, Netherlands Health System Review, Health System in Transition, Vol. 18 no.2, 2016 , p. 208
} 
of transparency in doctor-patient relationship is begun by an informed consent process which is based on transparency in communication that will lead to shared decision making. Shared decision making can be described as informed consent plus informed choice plus identify patients needs, values preferences and goals, to discuss uncertainity of treatment, experiences of providers and cost, and two way of conversation beetwen health provider and patient or family member has an important role in decision making. Informed choice can describe as informed consent plus make an assessment of patient understanding, to discuss about risks and benefits and also all of alternatives, and asking the patients or family member to choose treatment. In informed consent can be described as an explanation from doctor about nature of treatment, risks, benefits, alternatives of treatment, and giving opportunity for question to the patient and family member: ${ }^{17}$

Transparency is surgical field often required is not only transparency in an informed consent in general. Nevertheless, there are some things that may not be found in other medical fields, for example:

1. When recording or photos is needed

2. In the event of injury due to the extension of surgery procedure

3. Complications caused by previous surgeons

4. When there is a mismatch with the doctor of another field

5. The need to refer to more competent peers

6. Operation financing to avoid 'ghost surgery'

\section{SETTLEMENT ON MEDICAL DISPUTES DUE TO THE ABSENCE OF TRANSPARENCY PRINCIPLES IN INFORMED CONSENT OF SURGICAL PROCEDURE}

\subsection{Medical Dispute in the Field of Surgery and its Relation to Information Disclosure}

By the disclosure of information and the involvement of patients in decision-making of medical procedure, it will protect doctors from lawsuits. Obviously, this will work if a doctor has carried out a medical procedure according to ethical standards and profession. ${ }^{18}$ Naturally, doctor-patient relationship may run into a conflict.

Medical disputes, especially between doctors and patients, are primarily due to a patient's dissatisfaction towards an issue in a medical procedure or treatment where the patient assumes that the incident is due to the doctor's mistake. In the course of treatment, doctors and patients should be equally aware that it is impossible for the doctor to ensure that the treatment effort is fully successful in accordance with the wishes of the patient or his family; the doctor unlikely promises the outcome of the action or therapy given to the patient, but the doctor strives to do his best for the sake of the patient. This engagement is called an agreement of effort or known as verbintenis inspection, where both parties agree to make the best effort to achieve what has been agreed. ${ }^{19}$

According to data from the Indonesian General Surgeon Association (Persatuan Ahli Bedah Indonesia), during 2002-2006 there were 25 cases of medical disputes in surgery. This

\footnotetext{
${ }^{17}$ David Mayer, Transparency Begins with Informed Consent and Shared-Decision Making, posted on July 19,2012, available at: https://educate theyoung.wordpress.com

${ }^{18}$ Howard Brody, Transparency: Informed consent in Primary Care, The Hastings Centre Report, Vol.19(05), 1989

${ }^{19}$ Anny Isfandyarie, Tanggung Jawab Hukum dan Sanksi Bagi Doktrer Buku ke-1, Prestasi Pustaka, Jakarta, 2006, h. 62
} 
number does not include cases that may not be reported to the Persatuan Ahli Bedah Indonesia (PABI), as in most cases, non-death cases are immediately resolved in a familial manner before they are reported to the authorities. ${ }^{20}$ Unfortunately, there is no complete written data in the professional organization of surgeons. The majority of cases that occur are due to disagreement of opinions or expectations between patients and doctors. On the one hand, doctors assume that they have provided sufficient and clear information and done the best for the patients while the patients feel the explanation they obtained does not meet the outcome of the medical procedure performed by the doctors. This is where the openness or transparency of the parties is required. A doctor is obliged to disclose information about the illness and the medical treatment to be performed and should be open to give the patient a chance to seek a second opinion while the patient should not only provide open information about his or her situation and should be open to inquire if any information is not clear to him.

In a doctor-patient relationship, this agreement has existed since the patient comes to the health care facility or to the doctor's practice facility. In this case, doctors putting up a signage may be considered indirectly offering their medical services, although this offer cannot be equated with offerings in other respects such as business, because doctor-patient relationship is a unique relationship that is bound to professional ethics. While on the patient side, by coming and consulting with a doctor means having received an offer for medical services of the doctor. In this case, it can be said that the doctor and the patient have had an agreement and, hereby, the contract between doctor and patient has begun. In the Permenkes Number: 290/Menkes/PER/III/2008 Concerning Approval of Medical Procedure Article 2 paragraph 2, it is stated that the approval of medical action may be given in written form or orally, also in article 3, paragraph 4, it is stated that oral consent may be words or unwritten verbal statement, or a gesture of agreement such as a nod. These articles indicate that informed consent may actually be given orally, especially for non-high-risk procedures, as stated in the Permenkes in Article 3, paragraph 1 mentioned above, which states that "...any high-risk medical procedures must obtain written approval ...".

The problem is will come up again when a statement is required as evidence while the oral statement of the patient is not supported by sufficient witness. In this case, it will certainly put doctors in a weak position and will not provide legal protection for them. Unfortunately, Permenkes or other rules of legislation does not mention the limitation of the severity of the risk of a medical procedure. The Permenkes dealing with Approval of Medical Measures Article 1 only mentions the definition of medical procedure containing high risk, that is, a medical procedure based on a certain degree of probability and can result in death and disability. The "certain probability" statement cannot be used as an objective measure. One of the probability measure determinants may be the ability of a doctor as well as the patient's own condition. A similar medical procedure performed by different doctors on patients with different conditions will, of course, have a different probability of mortality or disability.

The doctor-patient relationship is essentially a form of contract that contains both parties' legal rights and obligations, in which the physician is deemed to have made an offer to the patient and performed the contract with the patient. Therefore, in a doctor-patient relationship, the doctor may be liable to breach of contract responsibility. Not all argue equally about breach of contract in doctor-patient relationships. Some assume that because

\footnotetext{
${ }^{20}$ Buletin Prabu PABI, Vol. 5, Januari-Juni 2006, h.31
} 
the engagement between the doctor and the patient is not considered as a resultant engagement, it cannot be classified as a breach of contract. In accordance with article 1365 $\mathrm{BW}$, the actions of doctors which deviate from the existing standards and cause harm to the patient is included as an act against the law. Sometimes it is not easy to determine whether malpractice is a breach of contract or an act against the law. Associated with article 1365 BW, a patient who postulates an unlawful act, he must prove there is an act against the law, in this case, the doctor's negligence or errors, although in practice it is very difficult for a common patient to prove a doctor's negligence or errors. ${ }^{21}$ The principle of burden of proof is not possible to prove a negative act (negative non sunt probanta), so this is used by the judge to perform the burden of proof. In practice, it is difficult to impose evidence on those who have to prove something negative. Sudikno Mertokusumo proposed the principle of reversal of proof (shifting of burden of proof/omkering van bewijslast).

Discussing doctor-patient relationships, of course, it cannot be apart from the three main frameworks:

1. Informed consent.

2. Medical Records

3. Medical Secrecy.

When depicted in a diagram, the relationship between those three things mentioned above is as follows. Those three things might rise in different way, but there will be a moment when they are interrelated. ${ }^{22}$

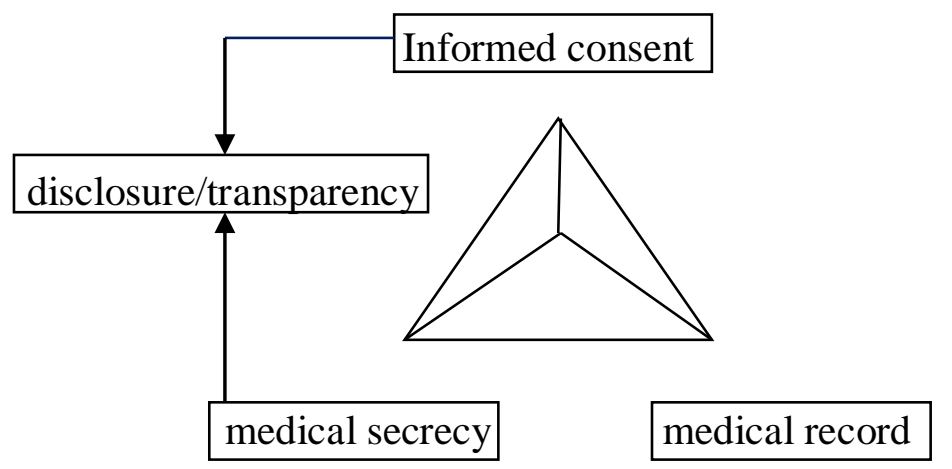

The linkage of the three main frames in a doctor-patient relationship

In certain situations, concerning transparency, doctors face difficult situation when the transparency about the disease as well the prognosis of the patient's illness might cause bad effects for the patient's mental condition. In this condition, the doctor is permitted not to disclose it. Or, in another situation, doctors should notify the patient's immediate family about the patient's illness and medical procedure to perform, but that will indirectly reveal the patient's secrets. This is related to the right to privacy. The patient has faith in the doctor that the doctor will not reveal his illness to others without his consent. ${ }^{23}$ The confidentiality of the patient is an important issue; there are even rules on criminal law in which doctors will be sanctioned if they divulge secrets. On one side and in certain situations, transparency or openness will be confronted with the patient's

${ }^{21}$ Wila Chandrawila Supriadi, Op.Cit., h.45

${ }_{22}^{2}$ J Guwandi, Trilogi Rahasia Kedokteran, FKUI, 1992, h.15

${ }^{23}$ Ibid., h.60 
confidential problem. Therefore, to provide legal certainty for health personnel, this confidentiality issue should be clarified and socialized with transparently.

\subsubsection{Medical Dispute Settlement Forum}

Doctors and patients must always hope that the medical or surgical procedures taken will get the results as expected. Nevertheless, sometimes discrepancy does happen; the expectation does not always meet the outcome. In this situation arise personal disputes and medical disputes. Disputes generally arise because of disagreements, differences, disruptions, competition, or imbalances between the parties. Disputes or conflicts may be caused by the following: ${ }^{24}$

1. Scarce resource, a significant scarcity of resources to the existence of conflict participants.

2. Ambiguous jurisdiction, where the boundaries of the authority or rights are mutually violated so that one party takes advantage of the other.

3. Intimacy, the closeness often leads to conflict due to unwell-managed differences.

4. We-they distinction, a condition in which people create opposite discrimination.

According to Texas Medical Association data, there are 10 things that get doctors sued: ${ }^{25}$

1. Failure to listen to patients, spending adequate time with them, and communicating empathically with them.

2. Maintaining illegible or incomplete documentation

3. Failure to establish standards of conducts for office staff.

4. Being inaccessible to patients.

5. Failure to order and follow up indicated tests or delay in ordering such tests.

6. Failure to refer when appropriate, failure to track referrals, and failure to communicate with referring physician.

7. Inappropriately prescribing medications.

8. Improper care of patients during emergency situations.

9. Failure to obtain informed consent.

10. Allowing noncompliant patients to take charge.

In contractual relationships the parties try to anticipate and prevent the occurrence of disputes, one of which is to include a dispute settlement clause. If the dispute arises in the end then the settlement, effort is taken through litigation (in court settlement) or through nonlitigation (out of court settlement). ${ }^{26}$ Due to some disadvantages of dispute settlement through litigation or through judicial institutions, it is generally preferable through a peace that has several advantages: ${ }^{27}$

a. The settlement is informal, in which both parties in dispute escape the rigidity of the law and use a conscience and moral approach; preferably the mutual equation of perception than the doctrinal approach and the principle of proof.

\footnotetext{
${ }^{24}$ Agus Yudha Hernoko, Penyelesaian Sengketa Kontrak Berdasarkan Asas Proporsionalitas, dalam Perkembangan Hukum Perdata di Indonesia, Laksbang Grafika, Yogyakarta, 2013, h.61 (Selanjutnya disingkat Agus Yudha Hernoko-3)

${ }^{25}$ Texas Medical Liability Trust, 10 Things That Get Physicians Sued, Published July 2009, downloaded from: www.tmlt.org

${ }^{26}$ Agus Yudha Hernoko-3,Op.Cit., h.68

${ }^{27}$ Ibid.., h.236
} 
b. The dispute is resolved by the parties themselves.

c. The timeframe for resolving the dispute is shorter.

d. Low cost.

e. Formal rules of evidence, often accompanied by battles against each other, can be avoided.

f. The process of settlement is confidential so that the reputation of both parties is remained maintained.

g. The parties' relationship is cooperative.

h. Prioritizing communication and focusing on completion.

i. Win-win solution

j. Free of emotion and revenge, but more towards kinship.

In accordance with Article 29 of the Law on Health, it is stated that "in the case of a health personnel suspected of negligence in carrying out his profession, the negligence shall be settled first through mediation." So, in the event of a medical dispute between the patient and the health personnel, in this case the doctor, either due to negligence or not a negligence, then the path chosen to resolve it is mediation. Unfortunately, so far, there are no specific rules governing mediation procedures in the cases of medical disputes. As the increasing number of medial disputes and their specificity compared to other general disputes, there should be a specific regulation that regulates it. Based on PERMA No. 1 of 2016 the mediation is divided into two stages: the pre-mediation stage and the mediation process stage.

According to Machli Riyadi, there are seven principles in the mediation of medical disputes: ${ }^{28}$

1. Good intention

2. Trust

3. Neutrality

4. Exclusive mediator

5. Open minded

6. Principal autonomy

7. Confidentiality

\section{Conclusion}

1. Surgical procedure has a different character from other medical fields that will affect the relation of surgeon and patient. The pattern of doctor-patient relationship in the form of fiduciary relationship which initially is paternalistic toward equality cannot be regarded as equal, but proportional. Informed consent is the process of exchanging information so that patients can use their autonomous right to determine a medical procedure for themselves. The principle of transparency is very important in the process of informed consent, as it reduces the risk of claim due to the patient's uncertainty. Transparency in the legislation of Permenkes Number 290/menkes/PER/III/2008 is implicitly listed, but not elaborated clearly. Transparency, on the other hand, faces the patient's confidentiality regarding the condition of the patient and to whom it can be transparently conveyed is still not clearly written, so it is prone to cause claims from the patient that the doctor has revealed his secret.

\footnotetext{
${ }^{28}$ Machli Riyadi, Op Cit., h.241
} 
2. Medical disputes due to conflicts between surgeons and patients are very frequent both in Indonesia and abroad. Several medical surgical dispute events are caused by information that is considered unclear, the outcome of a medical procedure is, as if, inconsistent with the contract. Patients are generally unaware that the doctor-patient relationship is a verbitant inspection and not a resultant engagement. If the doctor has made the best effort according to ethical and professional standards, then the doctor cannot be prosecuted by the patient. The misunderstanding about malpractice and medical risks in society may also cause medical disputes. In accordance with the provisions of the law, the settlement of non-litigation, in this case through mediation, is a way to be taken first before being brought to the court. However, it should be considered that mediation of medical disputes has certain characteristics compared to the mediation in other civil disputes.

\section{Suggestion}

1. It is necessary to apply the principle of transparency by doctors and patients to create a balance in doctor-patient relationships, among others are by:

a. Revision of Permenkes Number 290/Menkes/PER/III/2008 adjusted to the development of doctor-patient relationship, especially in terms of transparency standard.

b. The collegium of each field needs to set limits on the risk of medical action so as to protect doctor in the event of a claim by the patient.

c. Standardization of information form and informed consent as well as refusal consent, especially in the field of surgery that has specificity. The term doctor's charge should not be used and replaced with the term medical services or doctor's honorarium.

2. The efforts to reduce the risk of medical disputes, especially in the field of surgery, are as follows:

a. Communication as the main key to avoid the occurrence of medical disputes should be more emphasized on the doctor's and surgeon's education program which is expected to suppress the incidence of medical disputes.

b. Professional organizations as a vessel for doctors should play an active role in the mediation process in the event of a medical dispute. Documenting the case is expected to be lesson for the board and members of professional organizations in facing medical disputes.

c. The government through the Health Ministry needs to make specific regulation rules on mediation procedures of medical disputes because their characteristics cannot be equated with other fields. It should also be considered to legalize mediation decisions, for example by being registered to a court or through a notarial deed.

d. The hospital has an internal mediator who handles medical disputes, which is reinforced by legislation.

\section{REFERENCES}

[1] http://www.mnemonicdictionary.com

[2] Susan Ayers, Andrew Baum, Chris McManus, et al. Cambridge Handbook of Psychology, Health and Medicine, Cambridge University Press, 2007. p.506

[3] James W. Jones, Laurence B. McCullough, Bruce W. Richman., The Ethics of Surgical Practice: cases, dilemmas, and resolutions. Oxford University Press, 2008, p.7 
[4] Laurence B. McCullough, James W. Jones, Baruch A. Brody., Surgical Ethics, Oxford University Press, 1998, p.15

[5] Abdulkadir Muhammad, Etika Profesi Hukum, Citra Aditya Bakti, Bandung, 2006, p.58

[6] Robert M. Sade, The Ethics of Surgery: Conflicts and Controversies, Oxford University Press, 2015, p.20

[7]Alasdair Maclean, Autonomy, Informed Consent and Medical law, Cambridge University Press, 2013p.144

[8] Agus Yudha Hernoko-1, Hukum Perjanjian :Asas Proporsionalitas dalam Kontrak Komersial, Prenada Media Grup, 2010., h.75

[9] Karen Judson, Carlene Harrison, Law \& Ethics for Health Professions, McGraw Hill, New York, 2013, p.38

[10] Alasdair Maclean, Op.Cit,p.77

[11] Declaration on the Promotion of Patients' Rights in Europe, European Consultation of the Rights of Patients, Amsterdam 1994

[12] Ruth R. Faden, Tom L. Beauchamp, A History and Theory of Informed Consent, Oxford University Press, 1986, p.95

[13] Moch Isnaeni, Hukum Perikatan dalam Era Perdagangan Bebas, dalam Perkembangan Hukum Perdata di Indonesia, Laksbang Grafika, Yogyakarta, 2013, p.12

[14] Wil van der Aalst, Responsible Data Science Ensuring Fairness, Accuracy, Confidentiality, and Transparency (FACT), 2016, Available at: http://www.responsibledatascience.org/

[15] Shinning Light: safer health care through transparency, The National Patient Safety Foundation's Lucian Leape Institute, 2015,P.7

[16] Madelon Kroneman et al, Netherlands Health System Review, Health System in Transition, Vol. 18 no.2, 2016, p.208

[17] David Mayer, Transparency Begins with Informed Consent and Shared-Decision Making, posted on July 19,2012, available at: https://educate theyoung.wordpress.com

[18] Howard Brody, Transparency: Informed consent in Primary Care, The Hastings Centre Report, Vol.19(05), 1989

[19] Anny Isfandyarie, Tanggung Jawab Hukum dan Sanksi Bagi Doktrer Buku ke-1, Prestasi Pustaka, Jakarta, 2006, p. 62

[20] Buletin Prabu PABI, Vol. 5, Januari-Juni 2006, p.31

[21] Wila Chandrawila Supriadi, Hukum Kedokteran, Mandar Maju, 2001,p.45

[22] Shinning-light : safer health care through transparency, The National Patient Safety Foundation's

[23] J Guwandi, Trilogi Rahasia Kedokteran, FKUI, 1992, p.15

[24] Agus Yudha Hernoko, Penyelesaian Sengketa Kontrak Berdasarkan Asas Proporsionalitas, dalam Perkembangan Hukum Perdata di Indonesia, Laksbang Grafika, Yogyakarta, 2013, p.61

[25] Texas Medical Liability Trust, 10 Things That Get Physicians Sued, Published July 2009, downloaded from: www.tmlt.org

[26] Machli Riyadi, Hukum Kesehatan Kontemporer, Akademia, Malang, 2015., p.241 